\title{
Lactic Acidosis in a Clumber Spaniel
}

A three-year-old female Clumber spaniel was examined because of a history of poor exercisetolerance since puppyhood. The dog had the opportunity for free exercise and rest in its yard at home. Usually the symptoms became more evident when the dog was exercised on a lead. During exercise the dog tired quickly, started to pant and salivate, lay down and was unable to rise. After resting the dog always returned to normal condition rather soon, at the latest within an hour. Except for intermittent polydipsia the dog was otherwise healthy and in good clinical condition.

The owner contacted the Small Animal Hospital, Faculty of Veterinary Medicine, University of Helsinki, because of suspicion of the metabolic disorder, blood pyruvate dehydrogenase deficiency, which has been reported in Clumber spaniels (Herrtage \& Houlton 1979) and Sussex spaniels (Houlton \& Herrtage 1980) as a possibly inherited syndrome. This disorder represents a mitochondrial myopathy in which disordered energy metabolism in affected individuals, after minimal exercise, causes weakness and cramping due to lactate accumulation.

The preliminary plan was to examine the dog and check whether any lactic acidosis after exercise would be evident compared to the state of a clinically healthy dog and then try to identify the specific changes caused by the suspected disease, and not by the situation.

However, on arrival at the hospital the dog had totally collapsed. It was panting heavily and was unable to move, so it had to be carried to the examination room. The reason was assumed to be that the dog had walked on a lead for about 15 min while the owner was searching for the hospital.

In clinical examination, tachypnea and tachycardia were the main findings. Blood gas analysis (ABL 300, Radiometer, Copenhagen) from the heparin blood samples taken immediately after arrival from cephalic vein (venous) and about 45 min later from femoral artery (arterial) were performed showing extreme nonhypoxic acidosis (Table 1). Blood lactate values, examined for venous blood (Analox, Analox Instruments Ltd, London) immediately, $30 \mathrm{~min}$ and $60 \mathrm{~min}$ after arrival at the clinic were 18.6, 17.3 , and $13.4 \mathrm{mmol} / \mathrm{l}$ (resting value was impossible to get at that visit). The lactate values for a clinically healthy dog at rest, $15 \mathrm{~min}$ and 30 min after exercise (15 min of slow running), were $2.0,2.7$, and $1.7 \mathrm{mmol} / 1$, respectively. The post-exercise lactate values of the patient were thus very high compared with values for a healthy dog and confirmed the lactic acidosis. Blood samples for hematological and biochemical determinations were also taken at arrival. Routıne hematological parameters were normal as well as values for serum urea, cholesterol, triglycerides, creatınine, protein, alanine aminotransferase, aspartate aminotransferase, potassium, sodium and creatine kinase. The glucose value was slightly increased $(9.6 \mathrm{mmol} / 1$, reference values of the laboratory 4.0-6.4). After 90 min the dog was still depressed and unable to walk but returned to normal condition at home within some hours.

Unfortunately, after about 2 weeks this dog, 
Table 1. Blood gas analysis of a Clumber spaniel with lactic acıdosis

\begin{tabular}{llll}
\hline & \multicolumn{2}{c}{ Sample } & \\
\cline { 2 - 3 } & $1^{1}$ & $2^{2}$ & Reference values $^{3}$ \\
\hline $\mathrm{pH}$ & 6.910 & 7147 & $7.33-750$ \\
$\mathrm{PO}_{2}(\mathrm{kPa})$ & 12.0 & 154 & $11.3-12.6$ (arterial) \\
& & & $53-8.0$ (venous) \\
$\mathrm{PCO}_{2}(\mathrm{kPa})$ & 3.1 & 3.3 & $3.9-4.8$ (arterial) \\
& & & $3.9-5.6$ (venous) \\
$\mathrm{HCO}_{3}^{-}(\mathrm{mmol} / \mathrm{l})$ & 4.3 & 8.1 & $17-24$ \\
$\mathrm{ABE}^{4}(\mathrm{mmol} / \mathrm{l})$ & $\mathrm{ND}$ & -20.1 & \pm 2.5 \\
$\mathrm{SBE}^{5}(\mathrm{mmol} / \mathrm{l})$ & -25.8 & -189 & \pm 2.5 \\
\hline
\end{tabular}

1 Sample taken immediately after arrival (venous blood)

2 Sample taken 45 min later (arterial blood)

${ }^{3}$ From Bistner SI \& Ford RB: Kırk and Bistner's Handbook of Veterinary Procedures \& Emergency Treatment, 6th ed., WB Saunders Company, Philadelphia, 1995.

${ }^{4} \mathrm{ABE}=$ concentration of actual titrable base

${ }^{5} \mathrm{SBE}=$ concentration of standard titrable base

during a little exercise in the yard at home, suddenly died. In post mortem examination the main findings were severe congestion and edema in the lungs as well as hemorrhages and congestion in the brain and internal organs. The findings suggested acute cardiovascular complications (e.g. impaired myocardial contractility, ventricular arrhythmias, impared cardiovascular responsiveness to catecholamines) known to develop with severe lactic acidosis (DiBartola 1992). Histopathologically no special changes were found in the heart, muscles, or other organs. No electron microscopy or histochemical examinations were performed because several hours had passed since the dog had died.

The causes of nonhypoxic lactic acidosis include drugs and toxins, diabetes mellitus, liver failure, neoplasia, sepsis, and renal failure ( $D i$ Bartola 1992). None of these causes was verified in the history or examinations. Patients with an inherited deficiency of pyruvate dehydrogenase (PDH), a mitochondrial enzyme, exhibit rapid accumulation of pyruvate and lactate with minimal exercise, which is frequently lethal. PDH converts pyruvate into acetyl groups which are oxidized to $\mathrm{CO}_{2}$ in the tricarboxylic acid cycle. Under anaerobic conditions (e.g. tissue hypoxia) or in the deficiency of PDH, oxidative pathways are disrupted, and reduction of pyruvate to lactate occurs in the cytosol. Lactate accumulation leads to acidosis because the liver and kidneys, the main metabolizers of lactate, cannot rapidly utilize all lactate available for gluconeogenesis or for oxidation to $\mathrm{CO}_{2}$ and water.

In PDH deficiency cases reported in Clumber spaniels no histopathology including ultrastucture of mitochondria has been performed (Herrtage \& Houlton 1979). In man, however, inherited PDH deficiency is well characterized and consists of bizarre mitochondria and histochemical evidence of "ragged red» fibers (Harding \& Holt 1989).

Although the definitive diagnosis was not confirmed in the present case, the findings in this Clumber spaniel support PDH deficiency. The other dogs of the litter ( 3 males and 3 females) 
had no symptoms, with one dog not available for study. According to some breeders similar cases have been suspected, but no reports are available.

A-K Järvınen and S Sankarl,

Department of Clinical Sciences, Faculty of Veter1nary Medicine, Unıversity of Helsınkı, FIN-00014 Helsınkı, Finland.

\section{References}

DiBartola SP: Metabolic acidosis. In: SP DeBartola (ed.): Fluid therapy in small anımal practıce. Ed. S. P. DiBartola. WB Saunders Company, Philadelphia, USA, 1992, 216-243.

Harding AE, Holt IJ. Mitochondrial myopathies. Br. Med. Bull. 1989, 45, 760-771.

Herrtage ME, Houlton JE- Collapsing Clumber spaniels. Vet. Rec. 1979, 105, 334.

Houlton JE, Herrtage ME . Mitochondrial myopathy in the Sussex spaniel. Vet. Rec. 1980, 106, 206.

(Recelved September 20, 1995; accepted January 3, 1996)

Reprints may be obtained from: A-K. Järvınen, Faculty of Veterınary Medıcıne, Department of Clınıcal Veterınary Sciences, P.O. Box 57 FIN-00014 Helsınkı University, Helsınkı, Finland. 